は殆どみられません。

従って，術後に於ける呼吸機能への影響汃ら，手 術術式による侵蚝の差を考えてみますと，開胸して 肺を压排し縦隔内操作を行なう時間の長さに関連し て，最も大なるものは一期的胸腔内再趜術式であ り，最も小なるものは食道切除のみで開胸操作を終 る分割手術であり，一期的胸骨下又は胸壁前再建術 式は画者の中間に位置する様に思われます。
最後に私共の食道癌手術直接成績の変選をみます と（表 2), 昭和43年10月一期的手術の適応基 準 設 定以後の手術直接死亡率は, 術後管理の改善と相俟 って，4.2\%と著明に低下しました。良って Retrospective に求めました私共の基準は, 現時点に於け る一期的胸庤内再建の安全限界として, 臨床的に有 用な指標であると考えて居ります。

\title{
上腹 部手術
}

本学の一般外科（村上忠重教授）では，原則とし $\tau ， 60$ 才以上の高令者，既往に肺疾思のあるるの， 胸部の理学的所見ならびにレ線所見その他に異常が 認められるもの，あるいは肺活量や呼吸停止時間の 少ないもの，そういう症例を中央呼吸機能検查空に 送り肺機能障害の有無および程度を判定してもらっ ている。したがってこれからのべる应例は，そうい った症例であって，ある程度かきられており at random のものではない。

症例は最近の 308 例で, 過半数が60才以上であ る。まずてれらの应例について，衍前の肺機能スク リーニング・テストとして現在ひろく行なわれてい ろ肺活量およびその 1 秒率の意義を術後における患 者の予後ならびに肺合拼症発生の面から検討した。

ここにいう術後死亡とは退院までの全死亡であ り，術後肺合併症も退院するまでのもので外科の力 ルテに病名が明らかに記載されていたもののみであ ろ。涔名としては，主として肺炎，気管支炎，とき には喘息, 胸膜炎および膿演形成等もみられている。

全 308 例中，術後全死亡は16例 $(5.2 \%)$ ，術後肺 合併应は24例 $(7.8 . \%)$ である。

肺活量 (V C) 実測值之術後死亡および術後肺合併 症との関係について一術後肺合併症はV C $2000 \mathrm{ml}$ 以下と極端に少ない症例において発生率12.5\%で一 見多いようにみえるが，V C 3000〜 4000 ml の場合 の10.1\%にくらべて発生率に差異がなかった。また 術後死亡率についても V C 3000〜 4000 m10群に8.4 \%と最も高く，それよりも肺活量が少ない $3000 \mathrm{ml}$ 以下の群に死亡率はかえって低かった。

$\%$ 肺活量（\%VC）との関係について一術後死亡 率は，\%V C 80以下と高度拘束性障害例にわいて

\section{順天堂大学 麻酔科 佐 藤 光 男}

3.4\%。これはそれよりも\%V Cの良好な症例群に 比してむしろ低率で，\%V Cが低ければ死亡率う高 いとはいえなかった (正常例では 4〜6\%の死亡率)。 一方, 術後肺合併症は\%V C 80以下の群において $20.7 \%$ と約 5 名に 1 名のわりで発生し, 他の\%V C 良好群（発生率 $7 \%$ 未满）に比し明らかに高率であ つた。

1 秒率（\%F E V 1.0） との関係について，術後 死亡率は \% E E V1.0が60 以下の群において 7.1\% とやや多いかにみえるが，\%F E V1.080以上の症 例群の死亡率 $6.1 \%$ と大差なく，したがって\% E E $\mathrm{V}_{1.0}$ の低いものほど死亡率も高いとはいえなかっ た。また術後肺合併症については\% F E V1.060以 下の高度障害群 $(7.1 \%)$ よりも\% F E V 1.060 70 とやや良好な群で $17.5 \%$ 之，より頻発していた。か かる高度障害群に術後肺合併症が案外に少なかった のは，それだけ慎重な㭧者管理がなされていたこと を意味しよう。

以上を一応整理してみると，まず術後肺合併症の 発生率については，肺活量の実剆值よりも患者の年 令や体格を考慮した％VCおよび\%F E V 1.0の方 か関係深い。このととは今までもいわれてきたこと で，これらが高度に低下している症例では術後肺合 并症の危険が大きいと一応いえる。しかし一方，\% F E V1.0 が60以下と高度閉塞性障害例にかえって 術後肺合併症の発生がすくなく，てれは取りるなお さず愁者管理が十分であればある程度の肺機能障害 があっても手術に耐えられるととを意味しているか と思う。

また術後死亡についても，術前肺機能の瑟いもの． にかならずしも死亡率が高くなく，てれもてれらの 
定例では術前, 術中, 術後を通じて慎重な注意と管 理がなされた結果と思われる。本学では数年前より Intensive Care Unit (ICU) を開設し，とのよう な問題のある患者を術後数日間収容しているが，そ のようなことも効果があったと考える。

IPPB を衍前わこなうことについて一術前肺機能 に問題のあった約20例をえらび衍前 5〜7 日間 Bird レスピレーターをもちい1 日数回のIPPBをおこな ってみた。使用吸入薬は Racemic Epinephrine, Isoproferenol の気管支搪張刘を主とし，ときには 喀宛融解剂も添加した。その結果は，\%V Cおよび \%F EV1.0 の比較的よいものでは IPPBによって 一定の変化を示さなかったが，\%F E V1.0が60以 下の症列では多かれ少なかれその改善がみられた。 つまり IPPB は高度閉塞性障害に対して効果がある といえよう。また術後の経過も良好であった。

典型的な 1 例を示す。

74 才の肺気腫を伴う胃癌手術例。術前の \% V C 73 \%F E V1.066。I P P B後仙\%V Cは 74 と不変で あったが％Ｆ E V1.0 は 87 と改善された。本例の 術後を動脉血液ガスとの推移からみると, 術後 2 5 日は $\mathrm{pH}$ の上昇と $\mathrm{Pco}_{2}$ の下降すなわち埾度の呼 吸性アルカローシスの傾向を示し, $\mathrm{Po}_{2}$ は 2 日間の 酸素テント使用を中止後やや低目に経過している。 かかる変化は，かってしらべた60才以上の手術恵者 の術後血液ガスの推移と大体わなしで，とくに悪い 変化ではなかった。

てのように術前のIPPBは，とくに閉塞性障害に 対して效果ありと思う次第であるが，てのはかに私 共はたとえ IPPB で著明な改善が锠められなくて も，術前から IPPBに慣れておけば，もし術後に重 大な肺合併症がおきた際に抵抗なくIPPB療法が施 行でき，ての点でも役立つと芳えている。

かかる失敗例を示す。

71才の男。胃癌切除例。かって喘息があったとい う。手術前のIPPBはなし, 手術翌日より呼吸困難 があり，次第に強くなり意識も犯されてきたわけで あるが，そのわりには $\mathrm{PaCO}_{2}$ が低く $\mathrm{pH}$ が高く呼吸
性アルカローシスを維持しており,ただひとつ $\mathrm{PaO}_{2}$ のみが濑進的に低下し，最後は急性心停止により死 亡した症例である。との間しばしば Bird レスピレ 一ターでIPPBを試みているが，上手にできずに失 敗に終っている。死亡前日の胸部レ線写真は，手術 前のものと比較して，㭧者から察せられるほど強い 肺野の変化を示していなかった。

この症例は，はからずも術前にIPPBになれてお くことの必要性を示唆したが，そのはかに $\mathrm{PaO}_{2}$ 测 定の重要性についても物語っていると思う。

術後 $\mathrm{PaO}_{2}$ 測定の重要性についてーとの例におけ るように胸部レ線写賣で確帇な所見があらわれない のに $\mathrm{PaO}_{2}$ のみが輠進的に下降してくるとと。ての ようなととは本例以外にも経験するところで，たと えば次のような2例がある。いずれも本学胸部外科 白津が発表（日胸外会誌, 17巻 9 号, 昭44）してい るので, 詳細は略すことにするが, 大要は次のよう である。

68才の胃癌切除例。術前の\%V C は66,\% F E V 1.0 は76で峰度拘束性障害がある。術後は酸素テントに 収容していたが，24時間頃より酸素投与にもかかわ らず約 $80 \mathrm{mmHg}$ と下降, 肺変化 (肺炎像) は第 5 日になって認められ同時に発熱してきた。

82才の胃癌切除例。術前の肺機能テストには差し たる障害を認めない。術後は酸素テントにいれ約48 時間後に酸素投与を中止した。ところが $\mathrm{PaO}_{2}$ が $60 \mathrm{mmHg}$ 以下に下降, 再び酸素テントに収容, 第 5 日になってはじめて胸部レ線写真上に肺炎像があ らわれ，以後レスピレータ一等も使用して幸いに救 命しえた。

従来, 術後の肺合併症早期発見にいろいろな肺機 能テストが試みられているが，そのいずれも上腹部 手術患者の術後に用いるには負担が大きく，日常の 臨床には応用しがたい面がある。この意味からも $\mathrm{PaO}_{2}$ をしらべることは，簡単であるとともに，重 大なインフォーメーションをあたえるものと考え る。 